HoRTSCIENCE 26(3):307-309. 1991.

\title{
Phosphorus Application Constraints Limit Profitability of Sweet Corn and Lettuce Production
}

\author{
Jose Alvarez and C.A. Sanchez \\ Everglades Research and Education Center, University of Florida, Belle \\ Glade, FL 33430
}

Additional index words. Zea mays, Lactucu sativa, Histosols, phosphorus fertilization, economic optimal yields, profit maximization, non-point source pollution, eutrophication

\begin{abstract}
The economics of producing sweet corn (Zea mays L.) and head lettuce (Lactuca sativa L.) on Florida Histosols were analyzed with and without $P$ application constraints based upon quadratic response functions derived from two experiments with each crop. At the lower end of the historical price range, production of both crops is unprofitable, especially when $P$ is constrained. At higher prices, net returns for sweet corn under $P$ constraints are relatively small compared with the capital invested; net returns are higher for lettuce. However, an analysis of historical monthly prices showed that those high prices rarely occur. Values for the marginal contribution of the last unit of $P$ show that constraints greatly limit net returns. Many sweet corn and head lettuce producers may be forced out of business if $P$ fertilization rates are arbitrarily lowered below the economic optimal rate.
\end{abstract}

The production of high quality vegetables depends to a great extent on proper soil fertility. Capital for fertilizer expenditures is generally not limited in the United States. However, environmental concerns increase the possibility that fertilizer rates may be regulated. For example, P-enriched drainage waters from agricultural fields may affect neighboring wetlands (Cogger and Duxbury, 1984; Duxbury and Peverely, 1978; Miller, 1979). In many areas of the United States, vegetables are produced on Histosols (Lucas, 1982). Because Histosols used for crop production are often hydrologically linked to environmentally sensitive wetlands, legislation to limit P use is currently under consideration in Florida.

Another concern in Florida is the apparent incompatibility of $\mathrm{P}$ fertility regimes recommended for vegetables with those rec-

Received for publication 27 Apr. 1990. Fla. Agricultural Experiment Stations Journal Series no. R-00907. The cost of publishing this paper was defrayed in part by the payment of page charges. Under postal regulations, this paper therefore must be hereby marked advertisement solely to indicate this fact. ommended for sugarcane. Vegetables are often produced on rented sugarcane fallow land. However, soils with high P content can reduce sucrose (Yates, 1964). Therefore, many sugarcane producers limit the amount of $\mathrm{P}$ that vegetable growers may apply. In many cases where $\mathrm{P}$ has been restricted, vegetable yields and quality decreased. We undertook this economic analysis to compare profitability outcomes with and without $\mathrm{P}$ fertility constraints.

Field studies. Data from two $\mathrm{P}$ fertilizer experiments each with sweet corn and head lettuce were used in the economic analysis. The production practices used in these experiments have been described in detail (Sanchez et al., 1989, 1990). Briefly, the P rates applied in the sweet corn experiments were $\mathrm{O}, 25,50,75$, and $100 \mathrm{~kg} \cdot \mathrm{ha}^{-1}$; for lettuce they were $\mathrm{O}, 50,100,200$, and 300 $\mathrm{kg} \cdot \mathrm{ha}^{-1}$. All experiments were randomized complete-block designs with four replications. Other cultural practices were consistent with those commercially used in the area.

Data from the two experiments were combined to generate one generalized regression equation for each crop. Class variables were used to partition the variability due to ex- 
Table 1. Economic analysis of producing sweet corn with and without regulated fertility constraints at $\$ 2 / \mathrm{kg}$ per hectare of $\mathrm{P}$.

\begin{tabular}{|c|c|c|c|c|}
\hline \multirow[b]{2}{*}{ Economic optimum } & \multicolumn{4}{|c|}{ Sweet corn price $(\$ / t)^{2}$} \\
\hline & 157 & 315 & 472 & 629 \\
\hline \multicolumn{5}{|l|}{ No constraint case } \\
\hline $\mathrm{P}\left(\mathrm{kg} \cdot \mathrm{ha} \mathrm{a}^{-1}\right)$ & 50.3 & 85.3 & 87.5 & 88.3 \\
\hline Yield $\left(t \cdot \mathrm{ha}^{-1}\right)$ & 12.3 & 14.1 & 14.2 & 14.2 \\
\hline Net returns (\$/ha) & -2143 & 63 & 2287 & 4512 \\
\hline \multicolumn{5}{|l|}{ Constraint case } \\
\hline$P\left(k g \cdot h a^{-1}\right)$ & y & 84 & 84 & 84 \\
\hline Yield $\left(t \cdot h a^{-1}\right)$ & & 14.1 & 14.1 & 14.1 \\
\hline Net returns (\$ha) & & 62 & 2282 & 4501 \\
\hline Lambda $^{x}$ & & 0.6 & 2.8 & 5.1 \\
\hline$P\left(\mathrm{~kg} \cdot h a^{-1}\right)$ & y & 72 & 72 & 72 \\
\hline Yield $\left(t \cdot h a^{-t}\right)$ & & 13.8 & 13.8 & 13.8 \\
\hline Net returns $(\$ / h a)$ & & 24 & 2190 & 4355 \\
\hline Lambda & & 5.7 & 12.5 & 19.3 \\
\hline$P\left(\mathrm{~kg} \cdot \mathrm{ha}{ }^{-1}\right)$ & y & 60 & 60 & 60 \\
\hline Yield $\left(t \cdot h a^{-1}\right)$ & & 13.1 & 13.1 & 13.1 \\
\hline Net returns ( $\$ /$ ha) & & -75 & 1981 & 4038 \\
\hline Lambda & & 10.9 & 22.2 & 33.5 \\
\hline $\mathrm{P}\left(\mathrm{kg} \cdot \mathrm{ha} \mathrm{a}^{-1}\right)$ & 48 & 48 & 48 & 48 \\
\hline Yield $\left(t \cdot h a^{-1}\right)$ & 12.1 & 12.1 & 12.1 & 12.1 \\
\hline Net returns ( $\$ / \mathrm{ha})$ & -2143 & -237 & 1657 & 3551 \\
\hline Lambda & 0.1 & 16.0 & 31.9 & 47.7 \\
\hline $\mathrm{P}\left(\mathrm{kg} \cdot \mathrm{ha} \mathrm{a}^{-1}\right)$ & 36 & 36 & 36 & 36 \\
\hline Yield $\left(t \cdot h \mathrm{a}^{-1}\right)$ & 10.7 & 10.7 & 10.7 & 10.7 \\
\hline Net returns ( $\$ / \mathrm{ha})$ & -2148 & -460 & 1217 & 2893 \\
\hline Lambda & 0.7 & 21.2 & 41.5 & 61.9 \\
\hline$P\left(k g \cdot h a^{-1}\right)$ & 24 & 24 & 24 & 24 \\
\hline Yield $\left(t \cdot h a^{-1}\right)$ & 8.9 & 8.9 & 8.9 & 8.9 \\
\hline Net returns $(\$ / \mathrm{ha})$ & -2160 & -745 & 660 & 2066 \\
\hline Lambda & 1.3 & 26.3 & 51.2 & 76.1 \\
\hline
\end{tabular}

${ }^{2}$ Prices equivalent to $\$ 3, \$ 6, \$ 9$, and $\$ 12$ per crate.

${ }^{y}$ Constraint is higher than the unconstrained optimal solution.

${ }^{\mathrm{x}}$ Marginal contribution of last unit of $\mathrm{P}$ to net returns.

Table 2. Economic analysis of producing head lettuce with and without regulated fertility constraints at $\$ 2 / \mathrm{kg}$ per hectare of $\mathrm{P}$.

\begin{tabular}{|c|c|c|c|}
\hline \multirow[b]{2}{*}{ Economic optimum } & \multicolumn{3}{|c|}{ Head lettuce price $(\$ / \mathrm{t})^{z}$} \\
\hline & 264 & 529 & 793 \\
\hline \multicolumn{4}{|l|}{ No constraint case } \\
\hline $\mathrm{P}\left(\mathrm{kg} \cdot \mathrm{ha}^{-1}\right)$ & 199.0 & 207.4 & 209.1 \\
\hline Yield $\left(\mathrm{t} \cdot \mathrm{ha} \mathrm{a}^{-1}\right)$ & 45.3 & 45.3 & 45.4 \\
\hline Net returns ( $\$$ ha) & 1,665 & 13,678 & 25,651 \\
\hline \multicolumn{4}{|l|}{ Constraint case } \\
\hline $\mathrm{P}\left(\mathrm{kg} \cdot \mathrm{ha} \mathrm{a}^{-1}\right)$ & 180 & 180 & 180 \\
\hline Yield $\left(t \cdot h a^{-1}\right)$ & 44.8 & 44.8 & 44.8 \\
\hline Net returns ( $\$ /$ ha) & 1,637 & 13,498 & 25,315 \\
\hline Lambda $^{x}$ & 3.0 & 13.0 & 23.1 \\
\hline$P\left(\mathrm{~kg} \cdot h \mathrm{~h}^{-1}\right)$ & 150 & 150 & 150 \\
\hline Yield $\left(t \cdot h a^{-1}\right)$ & 43.1 & 43.1 & 43.1 \\
\hline Net returns (\$/ha) & 1,477 & 12,893 & 24,266 \\
\hline Lambda & 7.7 & 27.3 & 46.8 \\
\hline $\mathrm{P}\left(\mathrm{kg} \cdot \mathrm{ha}{ }^{-1}\right)$ & 120 & 120 & 120 \\
\hline Yield $\left(t \cdot h a^{-1}\right)$ & 40.3 & 40.3 & 40.3 \\
\hline Net returns ( $\$$ ha) & 1,175 & 11,860 & 22,505 \\
\hline Lambda & 12.4 & 41.6 & 70.6 \\
\hline $\mathrm{P}\left(\mathrm{kg} \cdot \mathrm{ha} \mathrm{a}^{-1}\right)$ & 90 & 90 & 90 \\
\hline Yield $\left(t \cdot h a^{-1}\right)$ & 36.5 & 36.5 & 36.5 \\
\hline Net returns (\$/ha) & 732 & 10,400 & 20,030 \\
\hline Lambda & 17.1 & 55.8 & 94.4 \\
\hline$P\left(\mathrm{~kg} \cdot \mathrm{ha}^{-1}\right)$ & 60 & 60 & 60 \\
\hline Yield $\left(t \cdot h a^{-1}\right)$ & 31.6 & 31.6 & 31.6 \\
\hline Net returns (\$/ha) & 148 & 8,511 & 16,843 \\
\hline Lambda & 21.8 & 70.1 & 118.1 \\
\hline
\end{tabular}

${ }^{2}$ Prices equivalent to $\$ 6, \$ 12$, and $\$ 18$ per carton. Optimal solutions were not obtained at $\$ 3$ per carton because harvesting and marketing costs are higher than price.

yValues for $P=210 \mathrm{~kg} \cdot \mathrm{ha}^{-1}$ are not reported because the constraint is higher than the unconstrained optimal solution.

Marginal contribution of last unit of $\mathrm{P}$ to net returns. perimental (soil and climate) conditions across the two site-seasons in each crop. The estimated equations were:

$$
\begin{array}{r}
\text { Sweet corn: } \mathrm{Y}=4.46+0.216 * \mathrm{P}- \\
0.0012 * \mathrm{P}^{2} R^{2}=0.86 \\
\text { Lettuce: } \mathrm{Y}=18.48+0.254 * \mathrm{P}- \\
0.0006 * \mathrm{P}^{2} \quad R^{2}=0.73
\end{array}
$$

All coefficients were statistically significant at $P<0.01$. An analysis of the residuals indicated that the quadratic function adequately described the response of these crops to $\mathrm{P}$. The general applicability of these equations is confirmed by the observation that $\mathrm{P}$ rates required for maximum yields were close to current soil-test $\mathrm{P}$ fertilizer recommendations for soils testing low in P (Sanchez, 1990).

Economic analysis. The $\mathrm{P}$ response equations were used to calculate maximum physical output and the corresponding $\mathrm{P}$ rates for each vegetable. Economic optimal conditions where $\mathrm{P}$ was not constrained were derived from the following profit equation: $\pi=\left(\mathrm{P}_{\mathrm{y}} * \mathrm{Y}(\mathrm{P})\right)-\left(\mathrm{C}_{\mathrm{P}} * \mathrm{P}\right)-(\mathrm{H} * \mathrm{Y}(\mathrm{p}))$ - $(\mathrm{PHC}+\mathrm{FC})$; where $\pi=$ profit $(\$ / h a)$; $\mathrm{P}_{\mathrm{v}}=$ price of the vegetable ( $\$$ per marketable ton); $\mathrm{Y}(\mathrm{P})=$ relevant response function $\left(\mathrm{t} \cdot \mathrm{ha}^{-1}\right) ; \mathrm{C}_{\mathrm{p}}=$ cost of $\mathrm{P}$ including application $(\$ / \mathrm{kg}) ; \mathrm{P}=$ rate of $\mathrm{P}$ application $\left(\mathrm{kg} \cdot \mathrm{ha}^{-1}\right) ; \mathrm{H}=$ harvesting and marketing costs $(\$ / t) ;$ PHC $=$ preharvest costs $(\$ / h a)$ and $\mathrm{FC}=$ total fixed costs $(\$ / \mathrm{ha})$.

Next, we solved the previous profit equation as a constrained maximization problem. A Lagrangean multiplier was used to define different levels of $\mathrm{P}$ fertilization for the two vegetables. Phosphorus application values for sweet corn, with a total need of $120 \mathrm{~kg} \cdot \mathrm{ha}^{-1}$, included 84, 72, 60, 48, 36, and $24 \mathrm{~kg} \cdot \mathrm{ha}^{-1}$, respectively. Phosphorus rates for lettuce, with a total need of $300 \mathrm{~kg} \cdot \mathrm{ha}^{-1}$, included 210 , $180,150,120,90$, and $60 \mathrm{~kg} \cdot \mathrm{ha}^{-1}$, respectively. The $60-\mathrm{kg}$ constraint is close to the one currently used by sugarcane producers in southern Florida.

Total preharvest costs were $\$ 1365 /$ ha for sweet corn and \$2447/ha for head lettuce. The fixed costs were $\$ 878 /$ ha for sweet corn and \$1220/ha for head lettuce (Taylor and Smith, 1989). Fixed costs were included because the decision of whether to produce under regulatory constraints is a long-run decision. The fertilizer cost figure in the budget was assumed to include $30 \%$ for fertilizer other than $\mathrm{P}$. The cost of $\mathrm{P}$ was $\$ 2.00 / \mathrm{kg}$, including application.

Harvest and marketing costs were $\$ 136 / \mathrm{t}$ of sweet corn and $\$ 133 / \mathrm{t}$ of head lettuce (Taylor and Smith, 1989). Vegetable prices were selected based on the historical range observed from the 1983-84 to the 1987-88 seasons (Fla. Dept. of Agr. and Cons. Serv.) For sweet corn, the range used was from $\$ 157$ to $\$ 629 / t$, or from $\$ 3$ to $\$ 12$ per crate of $19 \mathrm{~kg}(42 \mathrm{lb})$. For head lettuce the prices used ranged from $\$ 132$ to $\$ 793 / t$, or from $\$ 3$ to $\$ 18$ per carton of $22.7 \mathrm{~kg}(50 \mathrm{lb})$.

Maximum yield for sweet corn (14.2 t.ha' occurred at $90 \mathrm{~kg}$ of $\mathrm{P} / \mathrm{ha}$. Growing sweet corn is not economically feasible at the two 
lowest prices, regardless of $\mathrm{P}$ application (Table 1). At $\$ 315 / \mathrm{Mg}$, nominal returns are obtained when compared to the amount of capital invested. In the historical price data studied, prices lower than $\$ 300 / \mathrm{t}$ were quoted $50 \%$ of the time, whereas prices greater than $\$ 600 / \mathrm{t}$ were present only in three of the 48 prices studied.

Lambda values indicate the marginal contribution of the last unit of resource to net returns. They provide information on the productivity of added resources resulting from a relaxation of restraints. Since they represent the marginal change, these are overstated values. For example, if the $60 \mathrm{~kg} \cdot \mathrm{ha}$ constraint were relaxed, every additional unit of $\mathrm{P}$ would contribute $\$ 10.90$ to total net returns when the price of sweet corn is $\$ 315$ / 1.

Maximum lettuce yield of $45.4 \mathrm{t} \cdot \mathrm{ha}^{-1} \mathrm{oc}-$ curred at $211.7 \mathrm{~kg}$ of $\mathrm{P} / \mathrm{ha}$. At $\$ 132 / \mathrm{Mg}$, sales did not recover harvesting and marketing costs. At $\$ 264 / \mathrm{t}$, moderate net returns are obtained above the $60-\mathrm{kg}$ constraint, which is the maximum $\mathrm{P}$ application that sugarcane producers allow on their fields (Table 2). Higher net returns are obtained with higher prices. However, average monthly prices greater than $\$ 529 / \mathrm{t}$ were present in only 5 of the 37 months recorded. Lettuce producers, who are risk takers and own large amounts of capital, stay in business every year while waiting for favorable market conditions. It is very unlikely that the same attitude would prevail under severe fertility constraints. For example, net returns at $60 \mathrm{~kg} \mathrm{P} / \mathrm{ha}$ would be $\approx 62 \%$ of those in the unconstrained case at $\$ 529 / \mathrm{t}$, and $\approx 66 \%$ at $\$ 793 / \mathrm{t}$. Furthermore, the lambda values are much higher for head lettuce than for sweet corn, indicating that more net returns are sacrificed by each additional unit of $\mathrm{P}$ below the unconstrained optimal solution.

These data, which cover the range of $P$ fertilizer regimes used for vegetable production on Florida Histosols, clearly indicate that fertilizer inputs cannot be arbitrarily reduced without compromising the economic feasibility of crop production. However, if $\mathrm{P}$ used for agricultural purposes adversely affects environmentally sensitive wetlands, the use of $P$ at current rates can not continue indefinitely. Duxbury and Peverely (1978) indicate that improved fertilizer management offers the best means for reducing the adverse effects of $P$ fertilization. In many areas, fertilizer use efficiency can be increased by simply using a properly calibrated preplant soil test. Where soil tests are adequately calibrated and rates of $\mathrm{P}$ required for profitable crop production remain unacceptable, other management strategies such as placement, timing, and fertilizer protection must be pursued to improve fertilizer use efficiency. In southern Florida, most fertilizer used for vegetable production is applied preplant broadcast. However, recent work in Florida (Sanchez et al., 1990) indicates that rates of $\mathrm{P}$ required for lettuce production could be reduced by two-thirds without compromising crop yield and quality when the $\mathrm{P}$ was banded instead of broadcast. Clearly, future work must rigorously evaluate various management strategies, including cost differences, for improving fertilizer efficiency in an attempt to reconcile the economic realities of crop production with stewardship of the environment.

\section{Literature Cited}

Cogger, C. and J.M Duxbury. 1984. Factors affecting $\mathrm{P}$ losses from cultivated organic soils. J. Env. Qual. 13:111-114.

Duxbury, J.M. and J.M. Peverely. 1978. Nitrogen and phosphorus losses from organic soils. J. Env. Qual. 7:566570.

Fla. Dept. of Agr. and Cons. Serv. 1989. Fla. Agr. Stat., Vegetable summary 1987-1988. Orlando, Fla.

Lucas, R.E. 1982. Organic soils (Histosols). Formation, distribution, physical and chemical properties and management for crop production. Mich. State Univ. Res. Rpt. 435.

Miller, M.H. 1979. Contribution of nitrogen and phosphorus to subsurface drainage waters from intensively cropped mineral and organic soils in Ontario. J. Env. Qual. 8:42-48.

Sanchez, C.A. 1990. Soil- testing and fertilization recommendations for crop production on organic soils in Florida. Univ. of Fla. Tech. Bul. 876.

Sanchez, C. A., H.W. Burdine, and F.G. Martin. 1989. Yield and quality responses of three sweet corn hybrids as affected by fertilizer phosphorus. J. Fert. Issues 6:17-24.

Sanchez, C. A., S. Swanson, and P.S. Porter. 1990. Banding to improve fertilizer use efficiency of lettuce. J. Amer. Soc. Hort. Sci. 115:581-584.

Taylor, T.G. and S.A. Smith. 1989. Production costs for selected Florida vegetables, 1988-89. Univ. of Fla. Food and Resource Econ. Dept. Econ. Info. Rpt. 257.

Yates, R.A. 1964. Yield depression due to phosphate fertilizer in sugarcane. Austral. J. Agr. Res. 15:537-547. 